UDC 628.19: 614.445: 616-092.11

DOI: $10.21668 /$ health.risk/2020.3.06.eng

Research article

\title{
PRIORITY RISK FACTORS RELATED TO DRINKING WATER FROM CENTRALIZED WATER SUPPLY SYSTEM THAT CREATE NEGATIVE TRENDS IN POPULATION HEALTH
}

\author{
S.V. Kleyn ${ }^{1,2}$, S.A. Vekovshinina ${ }^{1}$ \\ ${ }^{1}$ Federal Scientific Center for Medical and Preventive Health Risk Management Technologies, 82 Monastyrskaya \\ Str., Perm, 614045, Russian Federation \\ ${ }^{2}$ Perm State University, 15 Bukireva Str., Perm, 614990, Russian Federation
}

Our research object was long-term dynamics of parameters describing drinking water from centralized water supply systems and additional cases of health disorders among population in Russia directly caused by low-quality drinking water.

Our research goal was to perform hygienic assessment of priority risk factors related to drinking water and potential health disorders that could be caused by them.

Our research technique was hygienic analysis of drinking water parameters as per data taken from the federal statistical form No. 18 entitled «Data on sanitary situation in a RF region» over 2000-2019, the federal information fund of social and hygienic monitoring over 2012-2019, and calculation of associated health disorders as per MG 5.1.0095-14.

Specific weight of centralized water supply sources that didn't conform to sanitary-epidemiologic requirements decreased by $4.7 \%$ over 2000-2019 and amounted to $14.9 \%$. Over the last 20 years there has been a descending trend in specific weight of water samples taken from centralized water supply sources that don't conform to sanitary requirements as per sanitary-chemical parameters (by $2.7 \%$ ) and microbiological parameters (by $4.8 \%$ ). Over 2000-2019, specific weight of water distribution networks not conforming to sanitary-epidemiologic requirements decreased by $10.7 \%$ and amounted to $15.9 \%$ in 2019.

Over the last 20 years there has been an increase in quality of drinking water taken from centralized distribution networks. Specific weight of water samples from centralized distribution networks not conforming to sanitary requirements as per microbiological and sanitary-chemical parameters fell by $6.7 \%$ and $7.9 \%$ respectively.

In 2012-2019 in the RF hygienic parameters of drinking water quality were the most violated as per contents of bromine, silicon, chlorine, iron, sodium, lithium, magnesium, manganese, chloroform, boron, strontium, sulfides, and hydrogen sulphide.

Overall, in the RF in 2019 more than 1.66 million cases of digestive diseases, cardiovascular diseases, diseases of skin and subcutaneous tissue, and other health disorders were directly related to drinking water being contaminated with chemicals and microbiological agents; it was by 13.3 \% lower than in 2012 regarding morbidity associated with drinking water quality. Priority risk factors were chlorine, chlorine organic compounds (COC), ammonia, iron, manganese, arsenic, nickel, copper, boron, magnesium, and other compounds.

Key words: drinking water, hygienic standards, health risk, associated morbidity, «Pure water» federal project.

Availability of qualitative and safe health of any nation [1]. Experts from the drinking water is a basic human right. Drink- World Health Organization (WHO) note that ing water is most significant for human health a lot of diseases can be prevented by safe waand it determines life quality and overall ter supply systems and strict adherence to hy-

(C) Kleyn S.V., Vekovshinina S.A., 2020

Svetlana V. Kleyn - Doctor of Medical Sciences, Associate Professor, Head of the Department for Systemic Procedures of Sanitary-Hygienic Analysis and Monitoring (e-mail: kleyn@fcrisk.ru; tel.: +7 (342) 237-18-04; ORCID: https://orcid.org/0000-0002-2534-5713).

Svetlana A. Vekovshinina - Head of Laboratory for conformity assessment techniques and consumer inspections (e-mail: veksa@fcrisk.ru; tel.: +7 (342) 237-18-04; ORCID: https://orcid.org/0000-0002-4833-0792). 
gienic requirements when it comes to drinking water supply. Only diarrhea diseases account for approximately $3.6 \%$ of the global diseases burden and they annually result in 1.5 million death cases all over the world. Approximately $58 \%$ out of them (842 thousand deaths per year including 361 thousand children younger than 5) are caused by safe water supply, hygiene, and sanitary not being available to people [2].

Water quality can also deteriorate due to infectious and parasitic agents, toxic chemicals, and other risk factors [3]. According to data provided by the WHO, in 2017 three out of each ten people all over the world were not provided with safe and easily available water supply at a place where they lived [4]. According to data provided by the UN, more than 2 billion people in the world do not have access to Clean drinking water, and more than 800 million people spend not less than 30 minutes every day on obtaining water or don't have any access to it at all [5].

Despite an increase in a share of RF population provided with safe drinking water in 2018 almost $10 \%$ of the country population was not provided with qualitative drinking water from centralized water supply systems ${ }^{1}$. Given that, a vital task set by the state authorities is to increase quality of drinking water supplied to the population in the RF.

«Clean water» Federal project envisages finding solutions to issues related to raising drinking water quality via modernizing water supply and treatment systems with the use of the most advanced technologies [6]. The Federal Service for Surveillance over Con- sumer Rights Protection and Human Wellbeing as well as other participants in «Clean water» Federal project have to tackle ambitious tasks: in 6 years time the project implementation should result in more than $90 \%$ of the RF population being provided with qualitative drinking water; the parameter should be equal to approximately $99 \%$ in urban settlements.

Risk assessment and management procedures are the most efficient tool for providing persistent safety of drinking water supply systems as they cover all the stages in water supply starting from water intake and up to water consumption [7-32].

Our research goal was to reveal and hygienically assess priority risk factors related to dirking water and potential health disorders among the RF population caused by them.

Data and methods. We performed hygienic analysis of drinking water from centralized water supply systems as per data taken from the Federal Statistic Report Form No. 18 entitled «Data on sanitary situation in a RF region» issued in 2000-2019 and data provided by the Federal information fund of social and hygienic monitoring (FIF SHM) over 2012-20192.

Provision of the overall RF population as well as urban population specifically with qualitative drinking water was assessed according to the methodical guidelines MR 2.1.4.0143-193.

Statistic data on population morbidity in the RF in 2012-2019 were provided by the RF Public Healthcare Ministry and applied as a source of data on population health in the country ${ }^{4}$.

\footnotetext{
${ }^{1}$ On sanitary-epidemiologic welfare of the population in the Russian Federation in 2018: The State Report. Moscow, The Federal Service for Surveillance over Consumer Rights Protection and Human Well-being Publ., 2019,254 p. (in Russian).

${ }^{2}$ Federal Statistic Report Form No. 18 entitled «Data on sanitary situation in a RF region» issued in 2000-2019. Zakon prost! Legal consulting service. Available at: http://www.zakonprost.ru/content/base/part/653252 (02.08.2020) (in Russian).

${ }^{3}$ MR 2.1.4.0143-19. 2.1.4. Drinking water and water supply in settlements. A procedure for assessing increase in quality of drinking water supplied via centralized drinking water supply systems. Methodical guidelines. Approved by the RF Chief Sanitary Inspector on March 27, 2019. KonsultantPlus. Available at: http://www.consultant.ru/document/cons_doc_LAW_325256/ (02.08.2020) (in Russian)

${ }^{4}$ Medical and demographic parameters in the Russian Federation: statistic reference book. Moscow, RF Public Healthcare Ministry Publ., 2018, 264 p. (in Russian).
} 
Table 1

The top $10 \mathrm{RF}$ regions and the worst 10 ones as per a share (\%) of population provided with qualitative drinking water from centralized drinking water supply systems in 2019

\begin{tabular}{|c|c|c|c|c|c|c|c|c|c|}
\hline No. & RF region & \multicolumn{3}{|c|}{$\begin{array}{c}\text { A share }(\%) \\
\text { of population }\end{array}$} & No. & $\mathrm{RF}$ region & \multicolumn{3}{|c|}{$\begin{array}{l}\text { A share }(\%) \\
\text { of population }\end{array}$} \\
\hline \multicolumn{5}{|c|}{ The top 10} & \multicolumn{5}{|c|}{ The worst 10} \\
\hline 1 & Saint Petersburg & - & 100.0 & - & 76 & Karachai-Cherkess & 66.3 & 61.5 & -4.8 \\
\hline 2 & Moscow City & - & 99.6 & - & 77 & Smolensk region & 63.1 & 60.2 & -2.9 \\
\hline 3 & Murmansk region & 99.7 & 99.4 & -0.3 & 78 & The Jewish Autonomous Area & 61.3 & 59.9 & -1.4 \\
\hline 4 & Kamchatka & 98.5 & 98.8 & 0.3 & 79 & Yakutia & 59.8 & 54.0 & -5.8 \\
\hline 5 & Kemerovo region & 98.3 & 98.3 & 0.0 & 80 & The Nenets Autonomous Area & 51.4 & 53.6 & 2.2 \\
\hline 6 & Sevastopol & 97.6 & 97.5 & -0.1 & 81 & Vologda region & 43.6 & 51.6 & 8.0 \\
\hline 7 & Kursk region & 93,6 & 95,9 & 2,3 & 82 & Buryatia & 44,1 & 46,5 & 2,4 \\
\hline 8 & Stavropol region & 98,5 & 95,3 & $-3,2$ & 83 & Transbaikalia region & 51,1 & 45,2 & $-5,9$ \\
\hline 9 & Magadan region & 98,5 & 95,3 & $-3,2$ & 84 & Tyva Republic & 24,5 & 24,7 & 0,2 \\
\hline 10 & Krasnodar region & 94,5 & 94,5 & 0,0 & 85 & Kalmyk Republic & 72,6 & 7,4 & $-65,2$ \\
\hline
\end{tabular}

We assessed a number of health disorders related to drinking water quality and revealed priority risk factors that caused them for the Russian Federation as a whole and RF subjects in particular according to Appendix 2 to the methodical guidelines $\mathrm{MR}^{5}$.

Results and discussion. We assessed whether target figures fixed in «Clean water» Federal project had been achieved; the assessment revealed that in 2019 an actual share of the RF population provided with qualitative drinking water from centralized drinking water supply systems amounted to $85.5 \%$ and it was lower than the target figure for the year $(87.5 \%)^{6}$.

Having analyzed data as per RF regions, we established that the target figure for 2019 fixed in «Clean water» Federal project hadn't been reached in 39 regions. The lowest values of the parameter were detected in Kalmyk Republic (7.4\%), Tyva Republic (24.7\%), Transbaikalia region (45.2\%), and Buryatia (46.5\%) (Table 1).

Other target declared within «Clean water» Federal project for 2019 (94.5\% of urban population in the RF should be provided with qualitative drinking water from centralized drinking water supply systems) wasn't reached either. The overall value in the country amounted to $93.2 \%$ and it was by $1.3 \%$ lower than declared in the project. In 2019 the highest shares of urban population provided with qualitative drinking water from centralized drinking water supply systems were detected in SaintPetersburg (100\%), Kabardino-Balkaria (100\%), Kamchatka (99.9\%), Murmansk region (99.7 \%), and Moscow city (99.6\%).

Analysis of data collected over 2000-2019 revealed that overall number of water sources used for centralized drinking water supply went down by more than 10.7 thousand (Figure 1). A share of underground water sources remained steady and was equal to approximately $98 \%$ (Figure 2).

Over the last 20 years a specific share of water sources that did not conform to sanitaryepidemiologic requirements decreased by $5 \%$. In $201914.9 \%$ water sources did not conform to sanitary requirements, $35.1 \%$ of them being surface ones.

${ }^{5}$ MR 5.1.0095-14 Calculation of actual economic losses and losses prevented due to control and surveillance activities regarding losses caused by population mortality, morbidity, and disability caused by negative effects produced by environmental factors. Approved by A.Yu. Popova, the Head of the Federal Service for Surveillance over Consumer Rights Protection and Human Well-being, the RF Chief Sanitary Inspector on October 23, 2014. KODEKS: an electronic fund for legal and reference documentation. Available at: http://docs.cntd.ru/document/1200129398 (03.08. 2020) (in Russian).

${ }^{6}$ The profile of «Clean water» Federal project. The RF Ministry of Construction, Housing and Utilities. Available at: https://minstroyrf.gov.ru/docs/17692/ (02.08.2020) (in Russian). 


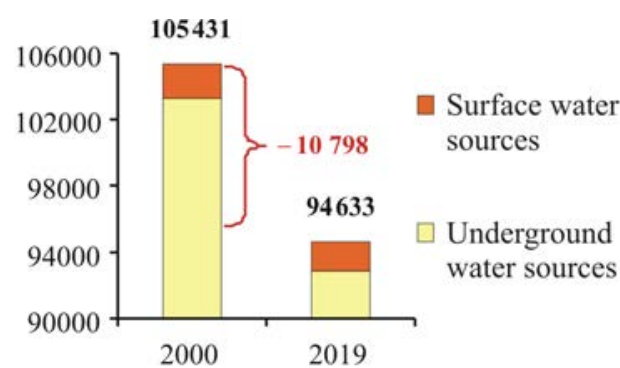

Figure 1. Quantity of surface and underground drinking water supply sources

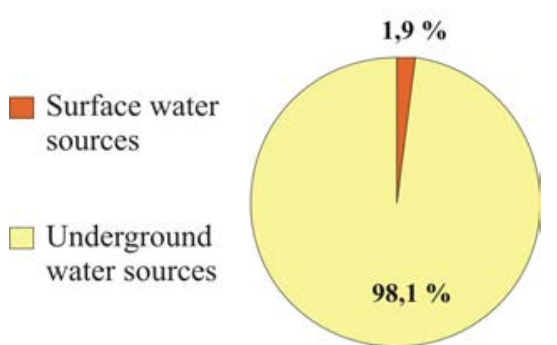

Figure 2. Shares of surface and underground drinking water supply sources, $2019(\%)$

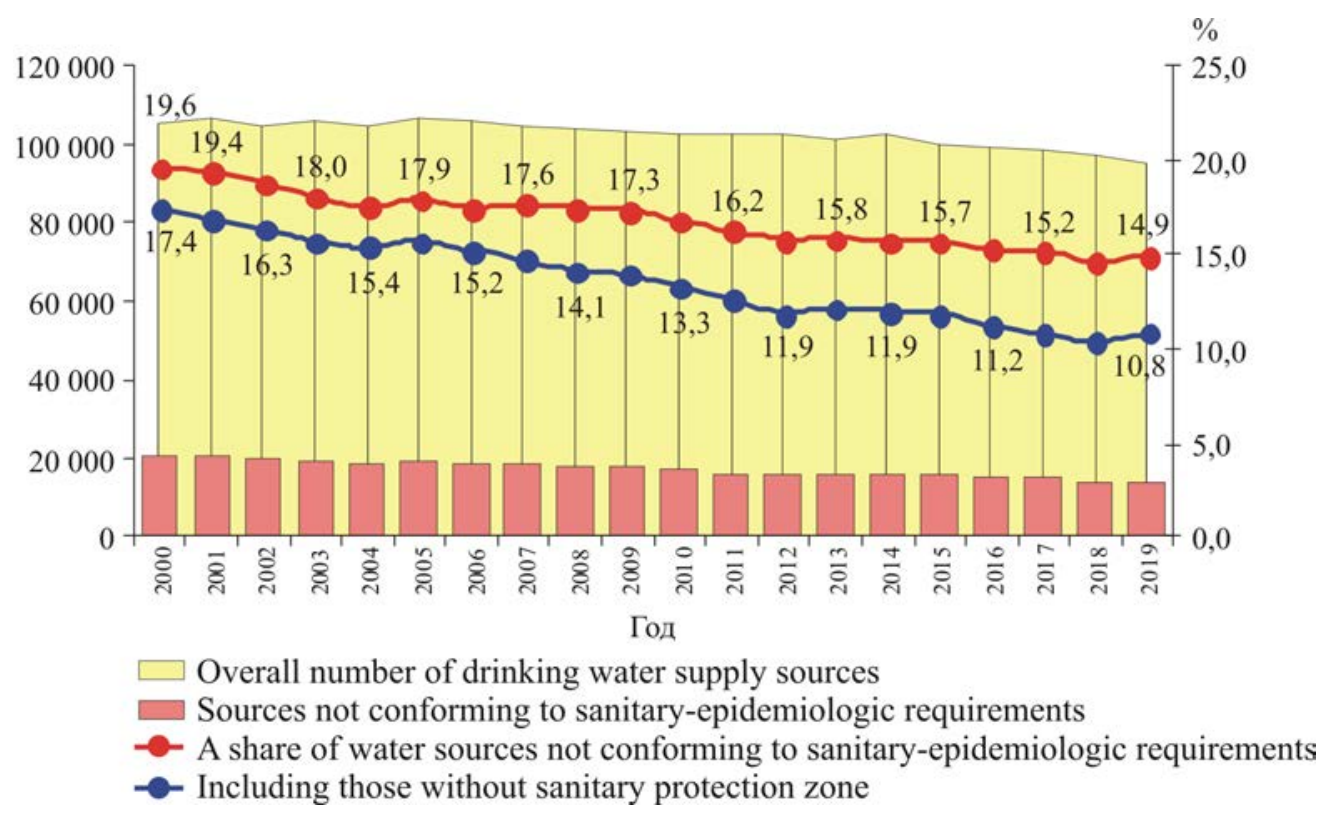

Figure 3. A specific weight of drinking water supply sources that do not conform to sanitary-epidemiologic requirements $(\%)$

Absence of sanitary protection zones remains the priority reason for drinking water supply sources not conforming to sanitaryepidemiologic requirements. Despite a number of sources used for centralized drinking water supply that didn't have any sanitary protection zone went down by more than $44 \%$ over the last 20 years (Figure 3 ), at present approximately 10.2 thousand water sources still don't have it. It is a significant risk factor that can produce negative effects on quality of drinking water taken from centralized water supply systems.

Better organization of sanitary protection zones around sources used for centralized drinking water supply and an increase in number of water sources conforming to sanitary requirements resulted in better quality of water taken from those sources.
Over 2000-2019 there was a 5\% decrease in a share of water samples taken from centralized drinking water supply systems that did not conform to hygienic standards as per microbiological parameters (the figure went down to $4.1 \%$ un 2019). But still, quality of water measured as per sanitarychemical parameters remains stable as approximately $25-28 \%$ water samples taken over the last 20 years from both surface and underground water sources do not conform to hygienic standards.

Quality of drinking water supplied to consumers via centralized water supply systems is determined not only by quality of water sources but that of supply networks as well. Number of supply networks operated in the Russian Federation increased over the last 20 years and amounted to more than 63.5 thou- 
sand in 2019. In 2019 more than 10.0 thousand supply networks $(15.8 \%)$ that supplied water from both surface and underground water sources did not conform to sanitary-epidemiologic requirements including more than 5.0 thousand $(7.9 \%)$ due to absence of necessary treatment facilities and more than 1.6 thousand $(2.7 \%)$ due to absence of disinfection equipment (Figure 4).

In 2000-2019 regional programs on building and reconstructing (modernizing) water supply networks including those developed within «Clean water» Federal project were implemented and it allowed reducing a share of water supply networks not conforming to sanitary-epidemiologic requirements by $10.7 \%$.

A growth in number of water supply networks that conformed to sanitary requirements allowed improving drinking water quality before it was supplied into distribution networks. Over the last 20 years a share of water samples taken from water supply networks that deviated from sanitary requirements decreased by $6.9 \%$ for microbiological parameters and by $4.8 \%$ for sanitary-chemical ones.

Improvements in quality of drinking water from supply networks influences quality of water in distribution networks. Analysis revealed that over the last 20 years a specific weight of water samples taken from distribution networks that didn't conform to sanitary requirements as per sanitary-chemical parameters decreased by $7.9 \%$, and as per microbiological ones, by $6.7 \%(2.7 \%$ in 2019) (Figure 5).

In 2019 a high share (more than $20 \%$ drinking water samples with chemicals contents being higher than MPC) of drinking water samples taken from distribution networks that deviated from sanitary requirements as per sanitaryepidemiologic parameters was detected in 22 RF regions; and as per microbiological parameters, in 17 regions (more than $5 \%$ drinking water samples with microbiological contents exceeding MPC). A share of samples taken from water distribution networks that deviated from sanitary requirements as per sanitarychemical parameters was higher than average country level in $49 \mathrm{RF}$ regions, and as per microbiological parameters, in $41 \mathrm{RF}$ regions.

The lowest quality of drinking water as per microbiological parameters was detected in 2019 in Karachai-Cherkess Republic (24.6\% samples deviating from hygienic standards), Ingushetia (20.7\% samples), and Chechnya (14.0\% samples); as per sanitarychemical parameters, in Kalmyk Republic $(58.3 \%$ with chemicals contents exceeding MPC), Karelia (43.1\%), Kostroma region $(38.0 \%)$, Chukotka (36.0\%), and Kurgan region $(35.2 \%)$.

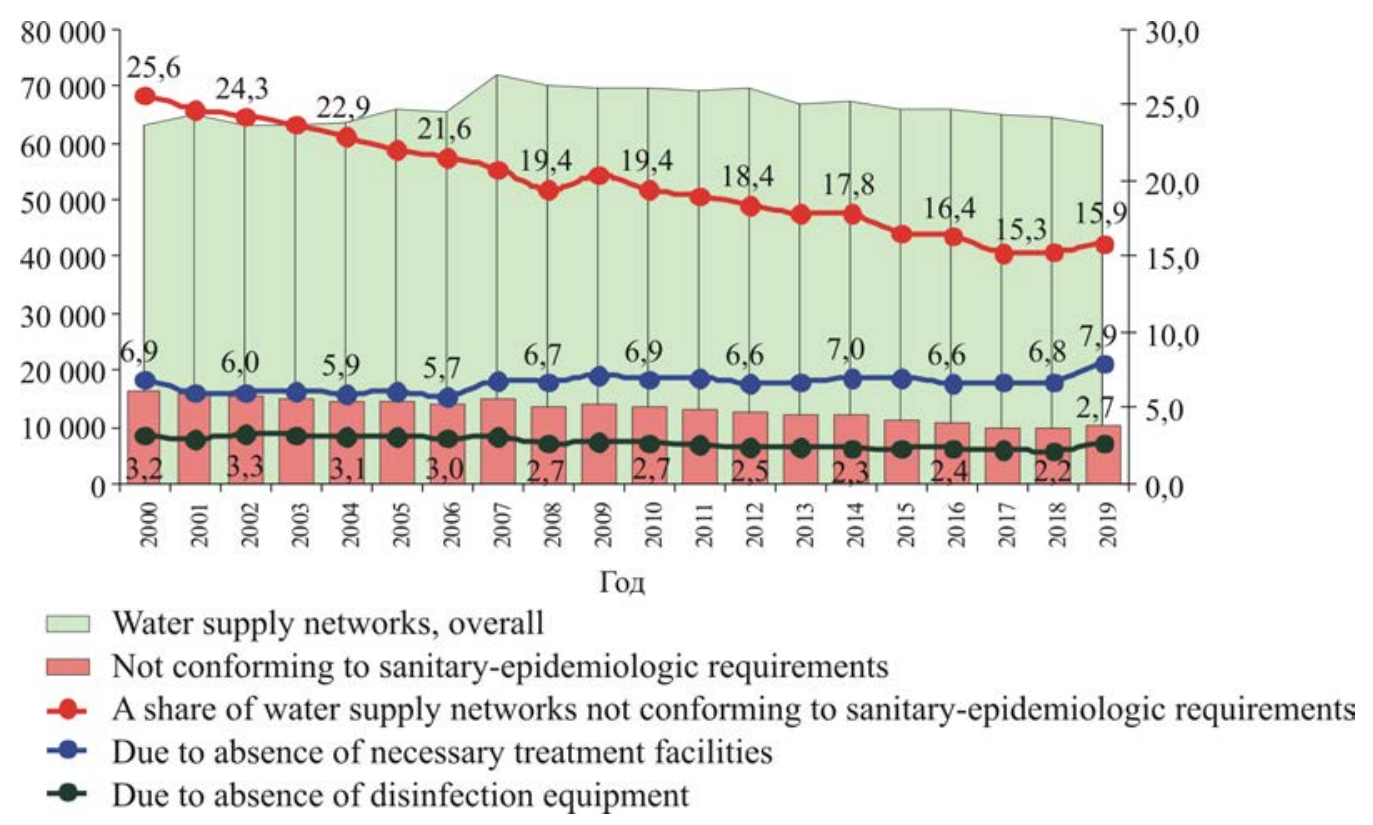

Figure 4. A specific weight of water supply networks no conforming to sanitary-epidemiologic requirements (\%) 


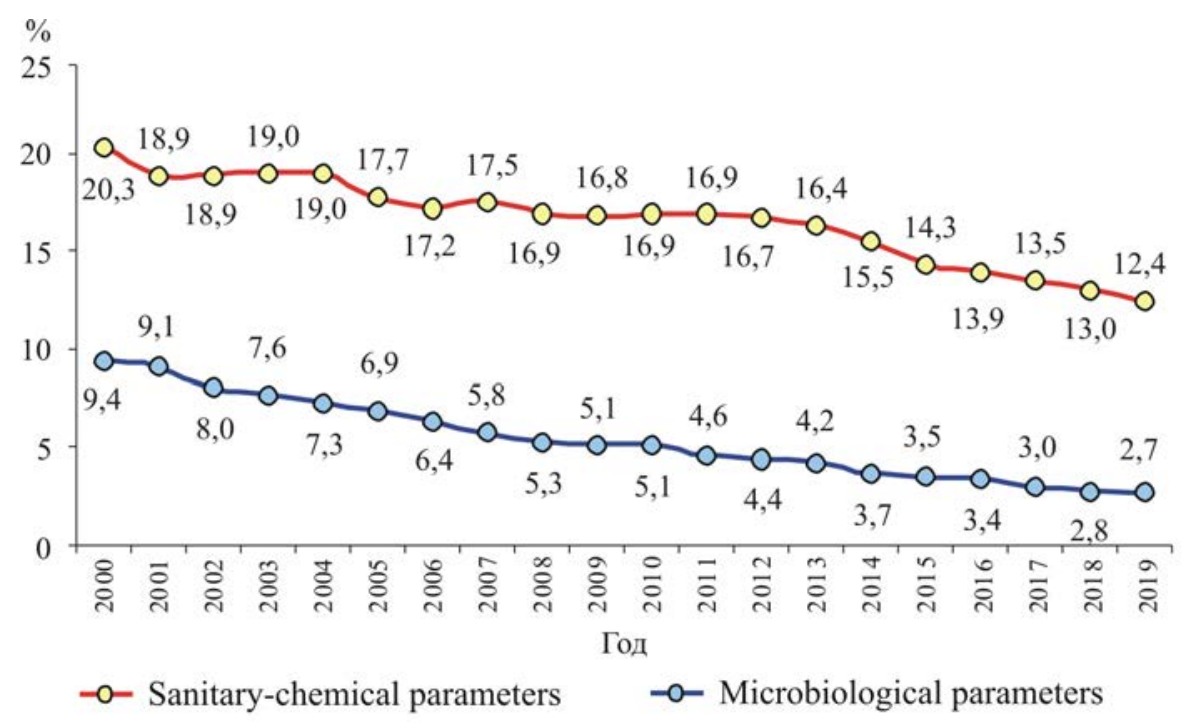

Figure 5. A specific weight of water samples from distribution networks not conforming to sanitary-epidemiologic requirements (\%)

Table 2

Priority chemicals influencing quality of drinking water taken from centralized drinking water supply systems

\begin{tabular}{|l|c|c|c|c|c|c|c|c|c|}
\hline \multirow{2}{*}{ Chemical } & \multicolumn{8}{|c|}{ A share of samples with contents higher than MPC } & Changes in the parameter \\
& 2012 & 2013 & 2014 & 2015 & 2016 & 2017 & 2018 & 2019 & over 2012-2019,\% \\
\hline Bromine & 8.87 & 61.02 & 43.94 & 20.0 & 60.0 & 50.0 & 75.0 & 100.0 & $+91.1 \uparrow$ \\
\hline Silicon (as per Si) & 4.09 & 6.21 & 20.54 & 24.86 & 22.92 & 22.72 & 20.99 & 18.9 & $+14.8 \uparrow$ \\
\hline Chlorine & 39.05 & 32.99 & 0.02 & 0.62 & 0.37 & 3.28 & 13.48 & 14.66 & $-24.4 \downarrow$ \\
\hline Iron (as per Fe) & 21.25 & 16.53 & 15.13 & 14.26 & 12.31 & 11.21 & 13.14 & 13.47 & $-7.78 \downarrow$ \\
\hline Sodium & 21.39 & 12.76 & 13.86 & 14.95 & 11.88 & 11.61 & 12.04 & 12.81 & $-8.58 \downarrow$ \\
\hline Lithium & 35.89 & 28.35 & 38.1 & 17.75 & 14.91 & 21.07 & 17.46 & 11.69 & $-24.2 \downarrow$ \\
\hline Magnesium & 11.75 & 8.34 & 7.35 & 8.7 & 8.06 & 7.72 & 10.15 & 9.81 & $-1.94 \downarrow$ \\
\hline Manganese & 10.6 & 7.1 & 7.1 & 6.92 & 6.31 & 6.82 & 7.19 & 9.81 & $-0.79 \downarrow$ \\
\hline Chloroform & 18.72 & 9.1 & 11.31 & 9.22 & 7.89 & 8.96 & 11.26 & 9.34 & $-9.38 \downarrow$ \\
\hline Boron & 4.51 & 6.29 & 8.55 & 8.69 & 8.36 & 6.98 & 8.05 & 8.52 & $+4.01 \uparrow$ \\
\hline Strontium & 1.26 & 6.96 & 4.14 & 3.5 & 5.58 & 7.93 & 6.01 & 7.16 & $+5.9 \uparrow$ \\
\hline $\begin{array}{l}\text { Sulfides and hydrogen } \\
\text { sulphide } \mathrm{H}_{2} \mathrm{~S}\end{array}$ & 6.63 & 5.21 & 2.84 & 1.41 & 1.49 & 3.79 & 5.49 & 6.7 & $+0.07 \uparrow$ \\
\hline
\end{tabular}

Contents of chemical contaminants in drinking water exerted their influence on drinking water quality as per sanitary-chemical parameters.

Having analyzed data collected by FIF SHM over 2012-2019, we determined the following priority chemicals in drinking water: bromine, silicon, chlorine, iron, sodium, lithium, magnesium, manganese, chloroform, boron, strontium, sulfides, and hydrogen sulphide. A specific weight of drinking water samples that contained these chemicals in con- centrations higher than fixed by hygienic standards was constantly higher than $5 \%$.

There were certain positive trends detected in 2012-2019; for example, there was a decrease in a share of drinking water samples deviating from hygienic standards as per chlorine (by $24.4 \%$ ), iron (by $7.78 \%$ ), sodium (by $8.58 \%$ ), lithium (by $24.2 \%$ ), magnesium (by $1.94 \%$ ), manganese (by $0.79 \%$ ), and chloroform (by $9.34 \%$ ).

However, over the same period of time there was an increase in number of drinking 
water samples that deviated from hygienic standards as per contents of bromine (by 91.1\%), silicon (by 14.8\%), boron (by $4.01 \%$ ), strontium (by $5.9 \%$ ), various sulfides and hydrogen sulphide (by $0.07 \%$ ).

When chemicals (chlorine and chlorinated organic compounds, ammonia, iron, manganese, arsenic, lead, nickel, copper, boron, magnesium, etc.) occur in drinking water in concentrations higher than MPC, it can cause additional cases of health disorders in the nervous, cardiovascular, endocrine, and urogenital systems as well as in digestive organs, skin and mucosa, blood system, and immune system, and it can also have certain effects on changes in body mass, development processes, and infectious diseases prevalence ${ }^{7}$.

We analyzed data provided by FIF SHM and state medical statistic data on population health in the RF collected in 2012-2019; the analysis revealed that approximately $1.98-1.68$ million disease cases in the country were caused by chemical and microbial contamination of drinking water from centralized drinking water supply systems.

Additional diseases cases among the overall country population that are directly caused by drinking water quality have its structure with the first rank place belonging to digestive organs diseases (37.0-37.8\%) followed by the diseases of urogenital system (26.0-27.4\%); skin and subcutaneous tissue diseases (12.7-13.7\%); diseases of the endocrine system, gastric and metabolic disorders (5.5-7.4\%); diseases of the musculoskeletal system and connective tissue $(4.8 \%-5.6 \%)$; neoplasms $\quad(5.2-5.5 \%)$. Other diseases account for $4.9 \%-6.8 \%$ of total additional cases.

Additional morbidity among the whole RF population with digestive organs diseases in 2012-2019 (423.6-522.1 cases per 100 thousand people, $12-14 \%$ of primary morbidity among the RF population with nosologies from this group) was probabilistically influenced by quality of water taken form centralized water supply systems deviating from sanitary requirements as per sanitary-chemical parameters including contents of arsenic, nickel, copper, boron, fluoride, chlorine, chloroform, and tetrachloromethane, in 79-83 regions in the country (Figure 6). Drinking water contamination that occurred in those regions probabilistically caused from 5.11 up

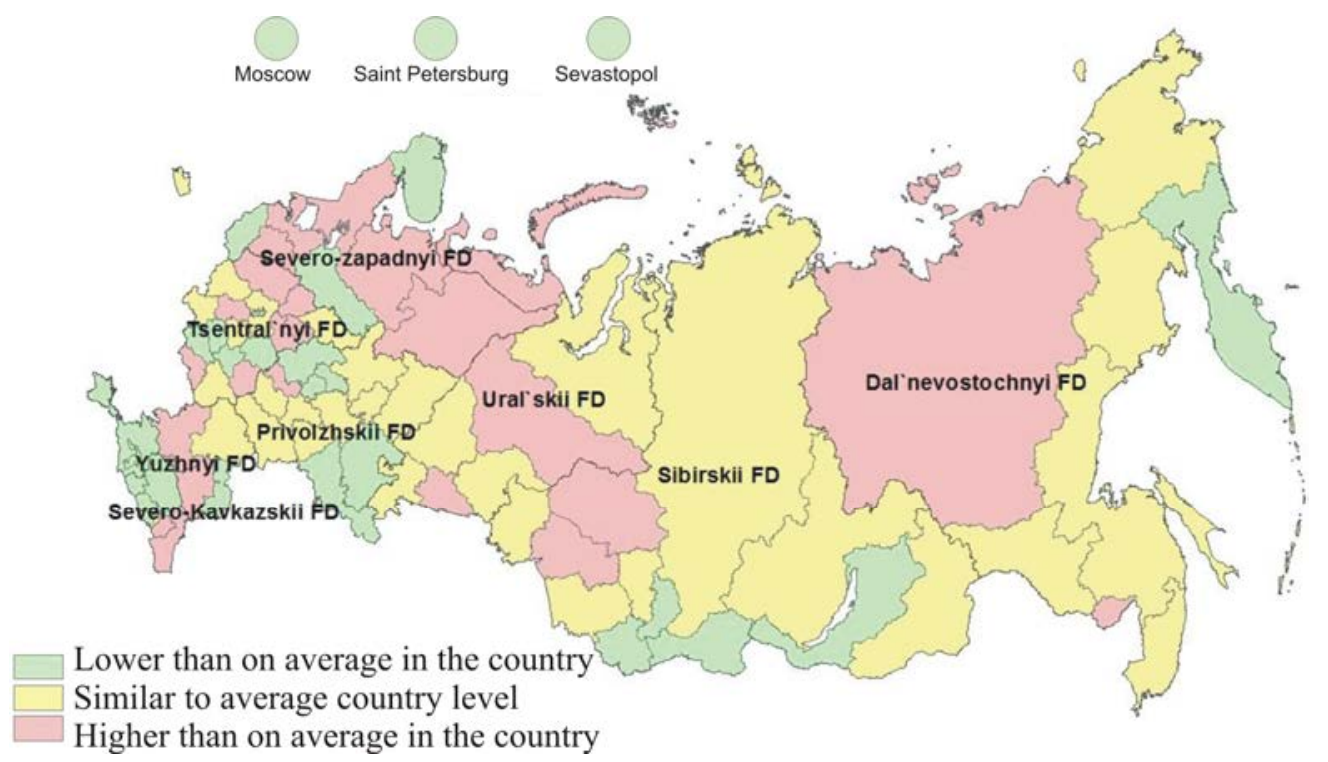

Figure 6. The RF regions distributed as per additional morbidity among the overall population with digestive organs diseases caused by poor quality of water taken from centralized water supply systems in 2019

${ }^{7} \mathrm{R}$ 2.1.10.1920-04. Guide on assessing population health risks caused by exposure to chemicals that pollute the environment. Moscow, The Federal Center for State Sanitary-Epidemiologic Surveillance of the RF Public Healthcare Ministry Publ., 2004, 143 p. (in Russian). 
to 2,450.5 additional cases of digestive organs diseases per 100 thousand people. In 2019 the greatest number of additional cases as per these nosologies was detected in Mordovia, Kalmyk Republic, and Dagestan, as well as in the Jewish Autonomous Area and Chechnya (from 1,276.38 to 2,233.67 cases per 100 thousand people).

Additional morbidity among the county population with urogenital system diseases (from 305.0 to 371.5 cases per 100 thousand people, $6.7-7.5 \%$ from primary morbidity with these nosologies on average in the RF in 2012-2019) caused by quality of drinking water deviating from sanitary requirements as per sanitary-chemical parameters including contents of boron, cadmium, lead, mercury, chloroform, tetrachloromethane, barium, etc., probabilistically occurred practically in all regions in the country (79-83 regions, from 3.75 to $1,728.5$ additional cases per 100 thousand people). In 2019 the parameter varied from 937.33 to $1,651.22$ additional cases per 100 thousand people in priority regions (Mordovia, Kalmyk Republic, Dagestan, the Jewish Autonomous Area, and Chechnya).

Additional cases of skin and subcutaneous tissue diseases caused by a high share of water samples deviating from hygienic standards as per arsenic and iron contents occurred in 79-83 RF regions 1.76-1,113.5 cases per 100 thousand people in 2012-2019). Primary morbidity with these nosologies was higher than on average in the country (147.4-188.6 additional cases per 100 thousand people, $3.4-4.0 \%$ of overall primary morbidity among population in 2012-2019) was detected in 22-39 RF regions (179.6-1,113.5 cases per 100 thousand people). In 2019 the parameter varied from 445.1 to 911.6 additional cases per 100 thousand people in priority regions (Komi, Mordovia, Kalmyk Republic, Dagestan, and the Jewish Autonomous Area).

In 2012-2019 additional morbidity among the RF population with endocrine system diseases, gastric and metabolic and disorders, directly caused by drinking water quality (deviation from hygienic standards as per contents of chloroform, arsenic, cadmium, lead, etc.) was registered in 79-83 RF regions (in 81 regions in 2019) and amounted to 74.0-94.8 cases per 100 thousand people on average in the country (5.6-8.9\% of primary morbidity with these nosologies among population). 16-32 RF regions were considered priority ones if taken in dynamics (86.5-952.2 cases per 100 thousand people): in 2018 there were 18 such territories including Komi Republic, Yakutia, Mordovia, Kalmyk Republic, Novosibirsk region, Tambov region, the Jewish Autonomous Area, etc. (from 130.3 to 857.8 additional diseases cases per 100 thousand people).

Additional cases of musculoskeletal system and connective tissue diseases among the overall TR population that were directly caused by poor quality of water taken from centralized water supply systems (as per strontium, fluorine contents, etc.) probabilistically amounted to 58.4-69.9 cases per 100 thousand people in 2012-2019 (2.0-2.4\% of all primary morbidity cases as per these nosologies). Additional morbidity with these nosologies caused by poor water quality was higher than on average in the country in 20-35 RF regions (74.8-436.1 cases per 100 thousand people). In 2019 there were 29 priority territories as per this parameter including Kalmyk Republic, Dagestan, Mordovia, the Nenets Autonomous Area, the Khanti-Mansi Autonomous Area etc. (101.6-305.3 additional morbidity cases per 100 thousand people).

Additional cases of neoplasms caused by drinking water quality deviating from sanitary requirements as per sanitary-chemical parameters (high contents of cadmium, arsenic, lead, tetrachloromethane, etc.) amounted to 61.3-74.3 cases per 100 thousand people on average in the country. Additional morbidity higher than on average in the country was detected in 22-36 RF regions (74.4-343.5 cases per 100 thousand people). In 2019 there were 22 priority regions as per this parameter including Mordovia, Kalmyk Republic, Chechnya, the Jewish Autonomous Area, Novgorod region, etc. (99.7-343.5 additional cases per 100 thousand people). 
Additional cases of certain infectious and parasitic diseases caused by poor drinking water quality probabilistically amounted to 39.2-65.9 cases per 100 thousand people for overall RF population (1.5-2.1\% of all primary morbidity with these nosologies). The parameter was higher than on average in the country in 22-29 regions. In 2019 maximum levels (more than 280.0 additional cases per 100 thousand people) were detected in the Jewish Autonomous Area, Chechnya, Karelia, Yakutia, Tyva, Karachai-Cherkess, Kalmyk Republic, and Ingushetia.

Overall, additional morbidity among country population (from 4,720.5 to 5,705.2 additional cases per 100 thousand people in 2012-2019) directly caused by poor drinking water quality was detected in 82-83 RF regions in 2019. In 2019 the greatest number of additional cases (from 3,727.7 to 5,705.2 cases per 100 thousand people) was detected in Mordovia, Kalmyk Republic, Komi, Chechnya, and Dagestan.

The research results revealed that the highest contributions into additional morbidity cases caused by poor quality of drinking water taken from centralized water supply systems were made by deviations from hygienic standards regarding chemicals contents in drinking water, namely arsenic, chloroform, nickel, chlorine, copper, boron, fluorine, tetrachlorometahne, cadmium, lead, mercury, barium, iron, strontium, as well as microbiological contamination.

Conclusions. We analyzed how frequently obligatory sanitary requirements to quality of drinking water from centralized drinking water supply systems were violated and how these violations were distributed in the country. The analysis revealed that over 2000-2019 quality of drinking water taken from centralized water distribution networks improved as per both microbiological and sanitary-chemical parameters. Specific weight of drinking water samples not conforming to sanitary requirements as per sanitary-chemical parameters went down by $7.9 \%$; and by $6.7 \%$ as per microbiological ones.

Hygienic assessment revealed that quality of drinking water taken from centralized water distribution networks not conforming to sanitary requirements as per sanitary-chemical and microbiological parameters could be considered a priority risk factor related to drinking water from centralized drinking water supply systems that created negative trends in a situation with population health in the Russian Federation.

Considerable concentrations of chemicals (arsenic, nickel, copper, manganese, iron, ammonia, chlorine, chloroform, boron, strontium, fluorine, etc.) and microbe agents in drinking water probabilistically cause more than 1.68 million additional morbidity cases among overall country population.

Basically adverse effects for population health occur in digestive organs, urogenital system, skin and mucosa, endocrine system, and musculoskeletal system; they also become apparent via a growth in number of neoplasms.

Priority risk factors that result in additional morbidity cases among population caused by poor quality of drinking water taken form centralized drinking water supply systems are violated hygienic standards regarding contents of arsenic, nickel, chlorine, copper, boron, fluorine, cadmium, lead, mercury, barium, iron, strontium, chlorinated organic compounds (chloroform, tetrachlorometahne, etc.) as well as microbial agents in drinking water.

Funding. The research was not granted any sponsor support.

Conflict of interests. The authors declare there is no any conflict of interests. 


\section{References}

1. Water sanitation hygiene. Water safety and quality. World Health Organization. Available at: https://www.who.int/water_sanitation_health/water-quality/en/ (03.08.2020).

2. Water sanitation hygiene. Diseases and risks. World Health Organization. Available at: https://www.who.int/water_sanitation_health/diseases-risks/en/ (03.08.2020).

3. Voprosy zdravookhraneniya. Voda [Healthcare issues. Water]. World Health Organization. Available at: https://www.who.int/topics/water/ru/ (03.08.2020) (in Russian).

4. Detail. Drinking-water. World Health Organization. Available at: https://www.who.int/newsroom/fact-sheets/detail/drinking-water (03.08.2020).

5. Vsemirnyi doklad Organizatsii Ob"edinennykh Natsii o sostoyanii vodnykh resursov, 2019 g.: Ne ostavlyaya nikogo v storone [The United Nations world water development report 2019: leaving no one behind, executive summary]. UNESDOC. Tsifrovaya Biblioteka. Available at: https://unesdoc.unesco.org/ark:/48223/pf0000367303_rus (03.08.2020) (in Russian).

6. Gorbanev S.A., Eremin G.B., Novikova Yu.A., Vyucheiskaya D.S. Federal project «Clean water». First results. Zdorov'e - osnova chelovecheskogo potentsiala: problemy i puti ikh resheniya, 2019, vol. 14, no. 1, pp. 252-259 (in Russian).

7. Bartram J., Corrales L., Davison A., Deere D., Drury D., Gordon B., Howard G., Rinehold A., Stevens M. Rukovodstvo po razrabotke i realizatsii plana obespecheniya bezopasnosti vody. Poshagovoe upravlenie riskami dlya postavshchikov pit'evoi vody [Guide on developing and implementing a program for providing water safety. Step-by-step guide to managing risks for drinking water suppliers]. Kopengagen, Evropeiskoe regional'noe byuro VOZ Publ., 2011, 108 p. (in Russian).

8. Zaitseva N.V., May I.V., Kleyn S.V., Sedusova E.V. An experience of establishing and proving of harm to the public health caused by consumption of drinking water containing hyperchlorination products. Zdorov'e naseleniya i sreda obitaniya, 2015, vol. 12, no. 273, pp. 16-18 (in Russian).

9. May I.V., Kleyn S.V., Sedusova E.V. To the question of the procedure of sanitary and epidemiological investigation of the infriengement of citizens' rights for safe drinking water supply. Zdorov'e sem'i - 21 vek, 2012, vol. 4, no. 4, pp. 11 (in Russian).

10. Zaitseva N.V., Kleyn S.V. Estimation of risk to health of the population at impact of water peroral factor of inhabitancy in conditions of large industrial centre for problems of sociallyhygienic monitoring (on example of perm). Izvestiya Samarskogo nauchnogo tsentra Rossiiskoi akademii nauk, 2009, vol. 11, no. 1-6, pp. 1139-1143 (in Russian).

11. Anisimov I.S., Mal'kova I.L. Sub-standard underground drinking waters of the Kezsky district of the Udmurt republic as a risk factor to the population health. Vestnik Udmurtskogo universiteta. Seriya Biologiya. Nauki o Zemle, 2018, vol. 28, no. 4, pp. 384-391 (in Russian).

12. Baidakova E.V., Unguryanu T.N., Krutskaya K.V., Minenko I.A. Quality of drinking water and epidemic risk of water-born infections in towns of the Arkhangelsk region. Ekologiya cheloveka, 2019, no. 5, pp. 15-20 (in Russian).

13. Orlov E.V. Quality of main water in residential units of Shchelkovsky district of the Moscow region. Stroitel'stvo: nauka i obrazovanie, 2017, vol. 7, no. 4 (25), pp. 31-37 (in Russian).

14. Sokrutina T.A. Ecological and hygienic assessment of drinking water quality. Epomen, 2018, no. 13, pp. 128-134 (in Russian).

15. Nefedova E.D., Khyamyalyainen M.M., Kovzharovskaya I.B., Shevchik G.V. Risk-oriented approach to the arrangement of drinking water quality control. Vodosnabzhenie $i$ sanitarnaya tekhnika, 2018, no. 3, pp. 5-9 (in Russian).

16. Stepanova N.V., Fomina S.F. Sovremennye metody otsenki regional'nykh faktorov riska dlya zdorov'ya naseleniya [Contemporary procedures for assessing regional health risk factors]. Innovatsionnye podkhody $v$ nauke i obrazovanii: teoriya, metodologiya, praktika: monografiya. In: G.Yu. Gulyaev ed. Penza, 2017, pp. 192-203 (in Russian). 
17. Kharina G.V., Aleshina L.V. Assessment of the Sverdlovsk oblast drinking water pollution with heavy metals. Vodnoe khozyaistvo Rossii: problemy, tekhnologii, upravlenie, 2020, no. 1, pp. 124-134 (in Russian).

18. Abramkin A.V., Rakhmanov R.S. To the question about the quality of drinking water system of centralized drinking water supply of republic of Mordovia. Zdorov'e naseleniya i sreda obitaniya, 2017, vol. 287, no. 2, pp. 41-43 (in Russian).

19. Akaizina A.E. Pokazateli kachestva vody tsentralizovannoi sistemy pit'evogo vodosnabzheniya i otsenka riska zdorov'yu detei [Quality parameters of drinking water taken from drinking water supply systems and assessment of risks for children's health]. Fundamental'nye i prikladnye aspekty analiza riska zdorov'yu naseleniya: materialy vserossiiskoi nauchno-prakticheskoi internetkonferentsii molodykh uchenykh i spetsialistov Rospotrebnadzora. In: A.Yu Popova, N.V. Zaitseva eds. Perm, Moscow, 2017, pp. 7-14 (in Russian).

20. Sereda T.I., Beregovskaya T.A. Sravnitel'naya otsenka kachestva vody tsentralizovannoi i netsentralizovannoi sistem pit'evogo vodosnabzheniya [Drinking water from centralized and noncentralized water supply systems: comparative assessment of quality]. Sovremennye kontseptsii razvitiya nauki: sbornik statei mezhdunarodnoi nauchno-prakticheskoi konferentsii, Perm, 2018, pp. 186 (in Russian).

21. Kokoricheva L.V., Manyk F.M. Volnoobuslovlennaya zabolevaemost', v Severo-Zapadnom Federal'nom okruge zavisyashchaya ot kachestva potreblyaemoi mineral'noi vody [Wave-like morbidity in the North-West Federal District dependent on quality of consumed mineral water]. Byulleten' Severnogo gosudarstvennogo meditsinskogo universiteta, 2019, vol. 42, no. 1, pp. 55-57 (in Russian).

22. Valeev T.K., Suleimanov R.A., Baktybaeva Z.B., Egorova N.N., Daukaev R.A., Rakhmatullin N.R. Ecological-hygienic assessment of the risk to public health of the republic of Bashkortostan, due to the quality of drinking water. Bezopasnost' zhiznedeyatel'nosti, 2017, vol. 203, no. 11, pp. 57-64 (in Russian).

23. Fridman K.B., Novikova Yu.A., Belkin A.S. On the issue of the use of health risk assessment techniques for hygienic characteristics of water supply systems. Gigiena i sanitariya, 2017, vol. 96, no. 7, pp. 686-689 (in Russian).

24. Kiku P.F., Kislitsyna L.V., Bogdanova V.D., Sabirova K.M. Hygienic evaluation of the quality of drinking water and risks for the health of the population of the Primorye territory. Gigiena i sanitariya, 2019, vol. 98, no. 1, pp. 94-101 (in Russian).

25. Kamenetskaya D.M., Popova A.A. Vliyanie sostava vody na zdorov'e naseleniya razlichnykh sub"ektov Rossiiskoi Federatsii [Effects produced by water composition on population health in different RF regions]. Byulleten' meditsinskikh internet-konferentsii, 2017, vol. 7, no. 6, pp. 1135 (in Russian).

26. Kovshov A.A., Novikova Yu.A., Fedorov V.N., Tikhonova N.A. Diseases risk assessment associated with the quality of drinking water in the urban districts of Russian Arctic. Vestnik Ural'skoi meditsinskoi akademicheskoi nauki, 2019, vol. 16, no. 2, pp. 215-222 (in Russian).

27. Solov'ev D.A., Dement'ev A.A., Lyapkalo A.A., Klyuchnikova N.M. Characteristic of drinking water quality and its influence on the health condition of population of some districts of the Ryazan region. Nauchno-meditsinskii vestnik Tsentral'nogo Chernozem'ya, 2019, no. 77, pp. 54-60 (in Russian).

28. Mekhant'ev I.I. Health risks for the population of the Voronezh region related to drinking water quality. Zdorov'e naseleniya i sreda obitaniya, 2020, vol. 325, no. 4, pp. 37-42 (in Russian).

29. Sinoda V.A., Zhmakin I.A., Kudrich L.A., Vasil'ev P.V., Kolesnik P.A., Al'-Gal'ban L.N., Markina A.D., Panasenko A.S. Condition of drinking water of systems of centralized and noncentralized economic and drinking water supply - an important factor of the habitat population of the personnel of the Tversk region. Tverskoi meditsinskii zhurnal, 2019, no. 5, pp. 7-17 (in Russian).

30. Poluyanov V.P., Poluyanova E.I. Tsentralizovannoe vodosnabzhenie i zabolevaemost' naseleniya Rossiiskoi Federatsii [Centralized water supply and population morbidity in the RF]. 
Aktual'nye voprosy ekonomiki i upravleniya: teoreticheskie i prikladnye aspekty: materialy chetvertoi mezhdunarodnoi nauchno-prakticheskoi konferentsii, Rostov-on-Don, 2019, pp. 616-622 (in Russian).

31. Abramkin A.V. The question of biogeochemical provinces and hygienic drinking water quality assessment. Sciences of Europe, 2016, vol. 8, no. 8-1, pp. 18-22 (in Russian).

32. Mukhamedova N.S., Maksudova N.A., Radzhabova N.A. K voprosu obespecheniya naseleniya Kashkadar'inskoi oblasti bezopasnoi pit'evoi vodoi [On an issue related to providing people living in Kaliningrad region with safe drinking water]. Vestnik nauki i obrazovaniya, 2016, vol. 16, no. 4, pp. $72-76$ (in Russian).

Kleyn S.V., Vekovshinina S.A. Priority risk factors related to drinking water from centralized water supply system that create negative trends in population health. Health Risk Analysis, 2020, no. 3, pp. 48-59. DOI: 10.21668/health.risk/2020.3.06.eng

Received: 07.06.2020

Accepted: 17.08.2020

Published: 30.09 .2020 